\title{
Lollard Women Priests?
}

\author{
by MARGARET ASTON
}

\begin{abstract}
7 he role of women in heresy has long been a matter for observation and comment. It must be attributed to historians' lack of interest, 1 rather than lack of evidence, that the Lollards have until now escaped analysis on this front. ${ }^{1}$ There are certainly grounds for supposing that they, like Cathars and Waldensians, derived a large measure of support from members of the female sex. In the fourteenth and fifteenth centuries, as earlier, unorthodoxy offered women outlets for religious activity that were not to be found in the established church." But, while the sources can tell us a good deal about women participating in the Lollard movernent as learners, readers and expounders of the gospel and other vernacular texts, the question of whether they ever advanced to the point of acting as priests is less easily answered. We know, indeed, very little about Lollard rites of any kind, and this makes it all the more worth while exploring fully what evidence we have. This little is enough to show that at one formative stage at least in Lollard development, claims were being advanced for women as capable of priesthood.
\end{abstract}

Contemporaries were in no doubt that lay women were actively caught up in Lollardy alongside lay men. Women became evangelists, expounding as well as studying the word of the anglicised gospel. Henry Knighton was one of the first to draw attention to this. "Women who know how to read' were among those 'swine' whose trampling on the

\footnotetext{
'We now have Claire Cross. "'Great Reasoners in Scripture": the activities of women Lollards 1380-1530', In Medieval Women, ed. Derek Baker (Studies in Church History thereafter cited as S.C.H.): Subsidia I), Oxford 1978, 359-80, which appeared after my article was written. I wish to thank Ame Hudson for drawing my attention to this paper and for her comments and suggestions.

"For comments on the role of women in earlier heretical movements see M. D. Lambert, Medieval Heresy: Popular Movements from Bogomil to Hus, London 1977, 76-7, 86, 9o. $114^{-16}, 158$; Brenda Bolton, 'Mulieres Sanctae', S.C.H., x (1973), 77-95, esp. 77 , So: G. Koch, Frauenfrage und Ketzertum im Mittelalter: Die Frauenbewegung im Rahmen des Katharismus und des Waldensertums und ihre sozialen Wurzeln (12-14.Jahrhundert), Berlin 1962. For the role of women in seventeenth-century sects see Keith Thomas, "Women and the Civil War Sects', Past and Present, xiii (1958), 42-62.
} 
evangelical pearl he so deplored. ${ }^{3}$ The Lollards, he insisted, seduced members of both sexes by their insidious teaching, and such was the method of their madness that both men and women were suddenly transformed into doctors of evangelical doctrine by means of the remacular". The same point was made by a late fourteenth-century preacher who stated in one of his sermons that women as well as men were to be heard spreading the Word in his time.

Behold now we see so great a dissemination of the Gospel, that simple men and women, and those accounted ignorant laymen in the reputation of men, write and learn the Gospel, and, as far as they can and know how, teach and scatter the word of God. ${ }^{5}$

Would God, he wondered rhetorically, appoint such persons as these to confound the pride of the worldly as a sign of the apocalyptic ending of the world?

Another such charge comes from Friar Daw's reply to Jack Upland. The heretics' frequently repeated censure of the friars as wife-stealers is here countered by the accusation that they were just as bad themselves.

3 Chronicon Henrici Kinghton. ed. J. R. Lumby, Rolls Series (hereafter cited as R.S.), London 1889-9.5, ii. 152 ; sec my 'Lollardy and Literacy', History. Ixii (1977), 360. In the heresy trials of Coventry and Lichlicld in 1511-12, nearly one-third of the accused were women; John Fines, 'Heresy Trials in the Diocese of Coventry and Lichfield, 1511-12', this JOURNAt, xiv $(1963), 161$. In the Norwich trials of $1428-31$ the proportion was about half this; 9 out of 60 accused were women. A point to bear in mind when considering women heretics is the possibility that they received more lenient treatment betore the law than men. This seems to be the case in the Norwich trials in respect not only of punishment, but also of procedure. Except in the case of Hawise Moon, who specifically requested an itemised point-by-point abjuration (which like that of her husband and other male heretics was recited by the accused or his spokesman), the female suspects were apparently expected to give only a general abjuration of the heresies imputed to them, atter these had been read out by a court official. Heresy Trials in the Diocese of Norwich, $1428-31$, ed. Norman Tanner (Canden Society, $4^{\text {th }}$ Ser., $x x, 1977$ ) (cited hereafter as Vorwich Heresy Trials), 24, 139, cf. 178-9. Cross, art. cit., 379, suggests that the total of Lollard women sentenced to burning (perhaps less than twelvel was disproportionatcly small considering the number who appear to have relapsed. On the relatively greater immunity of women from the law in a later period see the remarks of Peter Clark, 'Popular Protest and Disturbance in Kent, 1558-1640', Economic History Review, and Ser., .xix $(1976), 376-7$.

- Knighton, ed. Lumby, ii. 186 ; $\mathrm{cf} .187$ for the same emphasis on the Wycliffite address to 'both men and women:. There was of course a natural tendency to exaggerate in reporting such events; $\mathrm{cl}$. the description of the heretics of Périgueux about 1160 that "nobody is so stupid that if he joins them he will not become literate within eight days . . $:$ R. I. Moore, The Birth of Popular Heresy. London 1975, 80.

5 'Ecce iam videmus tantam disseminacionem evangelii quod simplices viri et mulieres et in reputacione hominum laici ydiote scribunt et discunt evangelium et quantum possunt et sciunt docent et seminant verbum dei.' Cambridge Lniv. Lib., MS Ii. 3.8 to. 149r.: quoted by G. R. Owst, Preaching in Medieval England, Cambridge 1926, 5-6, 135. 


\section{LOLLARD WOMEN PRIESTS?}

Who marrith more matrimonie, ye or the freris?

With wrenches and wiles wynnen mennes wyves

And maken hem scolers of the newe scole,

And reden hem her forme in the lowe chaier;

To maken hem perfit thei rede your rounde rollis,

And call on men for ther lessouns with 'Sister, me nedith'. ${ }^{6}$

Likewise the poet Hoccleve, dressing down Sir John Oldcastle in 1415 , blamed women for contributing to contemporary questioning of faith and scripture.

Some wommen eeke, thogh hir wit be thynne,

Wele argumentes make in holy writ!

Lewde calates! sittith down and spynne,

And kakele of sumwhat elles, for your wit

Is al to leeble to despute of it!?

Lollard teaching certainly helped to produce some well-schooled women in the fifteenth century. They included the Norfolk housewives Margery Baxter and Hawise Moon, whom Margery praised as 'a very discreet and very wise woman' in her knowledge of the teaching of William White. ${ }^{8}$ The arrogant self-confidence of female fundamentalists was noticed in passing by Reginald Pecock. Conceivably he had himself experienced the difficulties of discourse with

those women which make themselves so wise by the Bible, that they will allow no deed to be virtuous and to be done in man's virtuous conversation. save what they can find expressly in the Bible, and are most haughty of speech regarding clerks, and vaunt and advance themselves when they are in merriment and in their own houses to argue and dispute against clerks. ${ }^{9}$

Dogmatic assertiveness is perhaps not a surprising attitude among individuals whose textual skills brought them fame and leadership in

${ }^{6}$ Jack Upland, Friar Daw's Reply and Upland's Rejoinder, ed. P. L. Heyworth, Oxford 1968, 76. Cf. Pecock's remark about Lollard scripture-spouting 'upon their high benches sitting': The Repressor of Over Much Blaming of the Clergy, ed. C. Babington. R. S., London 1860, i. 129 . On Lollard 'rolls' (schedulae), the most ephemeral form of their literature which could, however, serve as compendia of doctrine see Anne Hudson, 'Some Aspects of Lollard Book Production', S.C.H., ix (1972), 149-50. In his comment on this passage Hevworth (p. 141) notes the pedagogic metaphor but says that 'the references to a lowe chair and rounde rollis probably imply that the womenis instruction was not religious but amorous'. Traducers of heretics rarely missed an opportunity to cast a slur of sexual misbehaviour, and that there are such insinuations in these lines seems obvious. This need not, however, exclude a genuine pedagogic setting, and the charge makes more sense if we accept the presence of women in Lollard schools.

'Hoccleve's Works. The Minor Poems, i. ed. F. J. Furnivall (E.E.T.S., Extra Series 61, 1892), 13.

${ }^{8}$ Norwich Heresy Trials, 41-51, at 47; J. A. F. Thomson, The Laler Lollards, 1414-1520. Oxford 1965, 123 ff. For these and other examples see Cross, 'Great Reasoners in Scripture'.

${ }^{9}$ Pecock, Repressor, i. 123 ; V. H. H. Green, Bishop Reginald Pecock, Cambridge 1945 , 90. 
their close-knit heretical communities-witness the sixteenth-century example of Alice Colyns described by Foxe. ${ }^{10}$ But did women ever advance beyond reciting, reading and teaching to the exercise of priestly functions? Claims were certainly made on their behalf.

According to Walter Brut or Brit, " who was arrested in 1391 and submitted in early October 1393, "women have power and authority to preach and make the body of Christ, and they have the power of the keys of the church, of binding and loosing'. ${ }^{12}$ A major argument in defence of this thesis was the ability of women to give baptism, on the grounds that since this was the most necessary of all the sacraments, if they could administer 'this chief sacrament, I dare not say they cannot administer the other sacraments'-in the absence of a competent ecclesiastical person. ${ }^{13}$ Moreover, whatever St Paul said about women not being allowed to teach, their ability to do so was another matter. For 'women, holy virgins, steadfastly (constanter) have preached the word of God and converted many to the faith, while priests hearing them dared not say a word." ${ }^{4}$ And since women who baptise absolve from sin, they must, having this power, have the power to bind and loose. Women were therefore not excluded from the Christian priesthood, though their power was restrained (refrenetur) in the presence of others ordained to these offices. Why should they not administer extreme unction, given their admitted right in baptism? So logically, concluded Brut, 'I dare not exclude them from the possibility of administering the body of Christ, though they ought not to proceed to do this while there are others constituted in the church for this purpose'. ${ }^{15}$ In the face of these

${ }^{10}$ Claire Cross, Church and People, 1450-1660, Glasgow 1976, 34. 37: Aston, 'Lollardy and Literacy', 355 .

"See below notes 18 and 19 for variants of his name. At his trial, where he is named Brut, the heretic made the imost of his 'British' ancestry. Registrum Johannis Trefnant Episcopi Herefordensis (hereafter cited as Reg. Trefnant), ed. W. W. Capes (Cant. and York Soc., $x x, 1916), 285,293-5$.

${ }^{12}$ Ibid., 364 , no. $30 ; \mathrm{cf} .279$ where the first of the points of which Brut was defamed was his assertion 'quod quilibet Christianus eciam mulier extra peccatum existens potest conficere corpus Christi ita bene sicut sacerdos'. On Brut's examination see K. B. McFarlane, John Wycliffe and the Beginnings of English Nonconformity, London 1952, 135-8.

${ }^{13}$ Reg. Trefnant, 345. On the ecclesiastical law providing that laymen, including women (in the absence of a man), could baptise in cases of necessity see $W$. Lyndwood, Provinciale, Oxford 1679, 241/f., Lib. III, tit. 24, esp. 241, n. b, Propter necessitacem, and 242, n. a, Foemina; also Councils and Synods, ed. F. M. Powicke and C. R. Cheney, Oxford 1964, 140, $896-7, \mathrm{cf} .182,233,368,45^{2}, 634,702-3$. There were, of course, Lollards who objected to baptism as an unnecessary rite.

14 Reg. Trefnant, 345. Variants of this passage appear in B.L. IS Harl. 31: fo. $201 \mathrm{v}$ 'mulieres ymmo et virgines constanter predicaverunt verbum dei et multos ad fidem converterunt sacerdotibus tunc non audentibus [audientibus, corrected] loqui verbum'; cf. lo. $21 \mathrm{gr}$ 'multe mulieres constanter predicaverunt verbum quando sacerdotes et alii non audebant verbum loqui et patet de Magdalena et Martha . . Brut cites St Paul in 1 Tim. ii. $11-12$ (cf. , Cor. xiv. 34-5) saying that 'docere mulieri non permittit neque dominari in virum'. But, comments Brut, Paul does not say 'quod tamen non possunt docere neque in virum dominari' (my italics).

${ }^{15}$ Reg. Trefnant, 345-7. 
arguments there is no surprise in Brut's further conclusion that there was no reason why women should not 'pray and bless equally with priests'. Brut therefore rested this case for women's ability to administer the sacraments on unorthodox, as well as orthodox practice. In addition to the long-established right of mothers and midwives to baptise in cases of necessity, he adverted to the successes of women preachers, hinting that a preaching pastorate might open the door to a fuller ministry.

Brut's case attracted a lot of attention. ${ }^{16}$ The bishop of Hereford, John Trefnant, collected quite a galaxy of university men, including fifteen doctors of theology, to refute the interminable outpourings of this educated layman, and the hearings were reported at unusual length in the bishop's register. " The assertions about women here form one of the thirty-seven points charged against Brut. The gravity of this error also left its mark elsewhere. Walter Brut's dual conclusions that women had the power and authority both to preach and to consecrate the body of Christ were fully answered in two sets of questiones which survive in manuscript. Both texts are anonymous and both pair the controversial issue of women priests with the commoner Lollard claims about preaching. In one case the discussion of "whether women can, as true priests, make the sacrament of the eucharist" lollowed arguments as to "whether every just layman is a priest of the new law'. In the other the question of 'whether women are suitable ministers to make (ad conficiendum) the sacrament of the eucharist', was linked to the issue of 'whether women are allowed to teach a public gathering of men'. ${ }^{18}$ Both these discussions (which alike

16 In addition to the determinations considered below and William Woodford's reply to Brut (below, n. 18), the 37 condemned conclusions of the heretic were registered at the end of a late fourteenth-century repertory of canon law belonging to the abbey of Reading. B.L. MS Royal to D X, fo. $312 \mathrm{r}-\mathrm{v}$

${ }^{17}$ Brut's case occupies pp. $278-394$ in the published register (tos 106v-128r). Much of the record consists of the defensive treatise Brut penned with his own hand after (he says) 'I was required to write a reply in latin to all these matters' (p. 28.5 ). Perhaps the authorities did not realise what they were letting themselves in for!

${ }^{18}$ Both texts are in B.L. MS Harl. 31 ; fos $194^{\mathrm{v}-196 \mathrm{v}}$ "Utrum liceat mulieribus docere viros publice congregatos'; fos $196 \mathrm{v}-205^{\mathrm{r}}$ 'Utrum mulieribus sint ministri ydonei ad conficiendum eukaristie sacramentum'; fos $216 \mathrm{r}-218 \mathrm{r}$ 'Utrum quilibet laicus iustus sit sacerdos nove legis'; fos $218 r-223 r$ 'Utrum mulieres conficiunt vel conficere possum ut veri sacerdotes eukaristie sacramentum. There is another copy of the latter pair of determinations in B.L. MS Royal 7 B III, fos. $1 \mathrm{r}-4 \mathrm{v}$ (to which Anne Hudson kindly drew my attention). Bale, followed by Tanner, suggested as the auchor of the former pair the Carmelite Walter Hunt (d. 1478), who has to be dismissed on grounds of date. John Bale, Scriptorum illustrium maioris Brytannie Catalogus, Basle 1557-9, i. 615-16; Thomas Tanner, Bibliotheca Britannico-Hibernica, London 1748,423. Another suggested candidate, William Woodford (various of whose works are in MS Harl. 31 ), is rejected for stylistic reasons by J. 1. Catto, 'William Woodford, O.F.M. (c. 1330-c. 1397)', (unpublished Oxford D.Phil. thesis 1969), 314. Woodford certainly participated in the refutation of Brut. He refers himself to his discussion of tithes, offerings and clerical temporalities in the 'letter' or 'history' which he sent to the bishop of Hereford against the book of 'Walter Britte'. $O$. Gratius, Fasciculus Rerum Expetendarum \& Fugiendarum, ed. E. Brown, London 1609, 220 , 222 (referring also to a 'certain determination'); A. G. Litte, The Grey Friors in Oxford, (Oxford Hist. Soc., xx, 1891 ), 248. 
focused their main attention on the topic of women as priests) were undoubtedly framed as answers to Walter Brut. One text refers to 'Walter Bryth' by name, quotes and answers him in the second person, and while the other generalises this to 'the Lollards' it also deals unmistakably with Brut's conclusions, similarly quoting both phrases and arguments to be found in the recorded trial. ${ }^{19}$ The overlapping between the two paired disputations is sufficiently close to suggest a common, or related authorship.

It seems likely on the face of it that the author, or authors, of these discussions were among the large body of academics (both regulars and seculars) present at Brut's trial. ${ }^{20}$ Among these perhaps the most probable candidates are Masters John Necton and William Colville, respectively chancellor and ex-chancellor of Cambridge, to whom was committed the task of answering the heretic's diffuse speculations. The two masters seem to have divided their forces, since they produced two sets of replies to Brut's thirty-seven condemned conclusions which, while much more concise than the heretic's own writings, still took up a substantial part of the trial record. ${ }^{21}$ Both replies to some extent regrouped the heresies listed by the bishop in his condemnation on 6 October 1393, and together they provided a comprehensive counter-argument. Only the second rebuttal, however, deals with the question of women priests, and it does so in a way which suggests that the complete presentation of the case extended beyond the limits of the registered version. Having indicated that Brut's assertions about women celebrants needed to be considered with his view of the sacrament and his denial that only priests could celebrate, the reply briefly stated the orthodox view of the eucharist, indicating that not only women but unordained men were excluded from celebrating this office. 'The doctors also establish', ended

\footnotetext{
19 There are relerences to 'Walterus Bryth' in MS Harl. 31, fos. 201v, 202r, and twice on lio. $204 \mathrm{v}$; cl: lios $219 \mathrm{gr}, 222 \mathrm{~T}-\mathrm{v}$ for allusions to Lollards. For parallels with the record in the bishup's register cl. Reg. Trefnant, 345-7, and MS Harl. 31, fos $201 \mathrm{v}-202 \mathrm{r}, 220 \mathrm{r}-\mathrm{v}$. The links between the two manuscript disputes, not only in argument, but in some passages of close verbal similarity (see below notes $34,3^{6}$ and 39 ) are such that 1 think one must postulate, if not common authorship, shared debate.

20 See Reg. Trefnant, 359-6o for the list of those present at the trial in October 1393 described by McFarlane, John Wycliffe, 137, as 'an absurdly large body of doctors'. Cl. ibid., 135 and idem, Lancastrian Kings and Lollard Knights, Oxford 1972. 170 for the suggestion (also made by Foxe) that Brut was a graduate of Oxford. Trefnant was a learned man himself; see A. B. Emden. Biog. Reg. of the Univ. of Oxford. Oxford 1957-9, iii. 1900-2. The large number of academics at the trial opens wide the possibilities of authorship, which include Nicholas Hereford, whose presence here may be presumed to have contributed to the attack on him as a turncoat (Reg. Trefnant. 394 fh). This question must therefore remain open; what is more important is that we can pinpoint the context of the debare. Since it is impossible here to give more than a summary I have given more attention to the heretical arguments, as being the more novel.

${ }^{21}$ Reg. Trefnant, 368-76 and 376-94 (an editorial error makes this section, wrongly, a reply to Swinderby). On Colville and Necton see A. B. Emden, Biog. Reg. of the Univ. of Cambridge, Cambridge 1963, 151,419.
} 
this paragraph, "that women do not have the power or authority to preach or make the body of Christ, and also that they do not have the power of the keys of the church, of binding and loosing, and the faithful ought to hold these conclusions and to shun the opposite as heresy.' ${ }^{22}$ This sentence could be read almost as a summary of the two related manuscript disputations on this topic.

Whoever penned the questiones, the role of the Cambridge doctors at Brut's trial certainly increased the likelihood of his extravagances being ventilated and controverted in that university. Lollard debates were not alien to Cambridge in the 1390 , for it was in this decade that John Devereux (or Deverose) was putting together the case for images against Lollard iconomachs. ${ }^{23}$ Perhaps it is also worth bearing in mind a negative point. The rebuttal of Brut's case for women teachers and women priests gives no hint of the actual existence of either; the whole debate was academic, confined to the realm of theory. Yet the theory itself is interesting, airing as it did so remarkably fully arguments for and against the spiritual equality of women.

You will not admit a point, objected Brut's opponents, unless it is lounded in holy scripture or natural reason. ${ }^{2+}$ The case for and against women ministrants therefore traversed both these grounds and included a lull statement (looking back to Aristotle's Politics among other sources) of the physical and mental inferiority which made women by nature unfit lor priesthood. ${ }^{25}$ The defence of women preachers naturally made the most of arguments from scripture, both in specific examples (in the Old Testament the prophesyings of Deborah and Huldah, wife of Shallum, or from the New Testament the cases of Mary Magdalen and the four daughters of Philip the evangelist, 'virgins, which did prophesy') and also in general injunctions, which meant that anyone in possession of wisdom and learning was duty bound to teach the ignorant, and that teaching,

${ }^{22}$ Reg. Trefrant, $3^{82-3}$; also below p. 453.

${ }^{23}$ Emden, Biog. Reg. Cambridge, 186 ; James Crompton, 'Lollard doctrine with special reference to the controversy over image worship and pilgrimages', (unpublished Oxford B. Litt. thesis 1950), 167ff. Foxe suggests, needlessly, that Brut's articles were 'sent to the university of Cambridge to be confuted'; Acts and Monuments, ed. J. Pratt, London $1853-68$, iii. 187 .

24 MS Harl. 31, fo. 204r, 'tu non vis admittere nisi scripturam sacram vel racionem naturalem. . . cf. fo. $21 \mathrm{gr}$, 'hac regula est lollardorum hoc non habetur ex sacra scriptura neque ex racione naturali ergo hoc non est ponendum'. Cf. Brut's protestations that he will freely submit to corrections 'ex auctoritate scripture sacre aut probabili racione in scriptura sacra lundata ... Reg. Trefnant, 285-6, 358.

${ }^{25}$ References to Aristotle's Politics in the context of women's deficiency of reason and unsuitability lor the rule of bodies (and therefore. much more so, of souls) appear in MS Harl. 31, los 20or, 218r. Cf. The Politics of Aristotle, trans. Ernest Barker, Oxford 1946, 35-6. 75-6: St Thomas Aquinas, In Libros Politicorum Aristotelis Expositio, ed. R. M. Spiazzi. Turin and Rome 1951, 49, para. 159, 72, para 218, 99-100, paras. 301, 303. For a summary of the biblical and other grounds for this traditional theory of female subjection see D. S. Bailey, The Man-Woman Relation in Christian Thought, London 1959, 15-16, 62-4. $157,293-6$. 
being a work of mercy, was not forbidden to anyone. ${ }^{26}$ To prophesy was to preach and the women prophets of the Bible were therefore precedents for women preachers.

The claim for women to be priests was partly an extrapolation from this overriding obligation to preach. The heretics argued, according to their opponents, that every priest can ex officio preach the gospel publicly; women can also rightfully preach; therefore they are priests. ${ }^{27}$ But there was also another major line of approach-the Donatist one, which impugned the ministry of evil priests and grounded office on merit. 'Every holy person is a priest' and 'every good elect woman is holy; therefore every such one is a priest.' The argument from worth, bonitas, operated both positively and negatively, both to choose and exclude. 'A good layman and good woman is worthier than an evil priest, and therefore more suited to the worthy work of consecrating, for making the body of the lord is the worthiest work and therefore the good layman and good woman is more suitable for it. ${ }^{28}$ Virtue singled out the righteous and the operations of the evil were worthless. The sinful priest, on account of his lack of goodness, defectum bonitatis, does not consecrate, whereas the virtuous lay woman, effectively ordained by the sacramental words ('Take, eat . . . this do in remembrance of me': 1 Cor. xi. 24 ) was a proper ministrant. The holy spirit operates 'more through the good layman and the holy woman than through the evil priest'. 'So if a woman has goodness of life and is ordained, why can she not consecrate?'29

Brut's opponent devoted considerable attention to refuting this heretical view of sacerdotal office, showing what complete confusion it would lead to. And, though the administration of the eucharist was the

${ }^{26}$ MS Harl. 31, fos $194 \mathrm{v}-196 \mathrm{r}$, citing Judges iv. 4 fl; 2 Kings xxii. 14ff; Acts xxi. 8-9: 1 Cor. xi. 5 ("every woman that prayeth or prophesieth ...); 1 Cor. xiv. 5 ('I would that ye all spake with tongues, but rather that ye prophesied...'), and I Peter iv. 10 ('minister the same Igiftil one to another ...'). In reply to these claims it was stated that there were three cases in which women could publicly teach (which explained these examples): i. by special privilege, as in the example of Huldah; ii. to bring ignominy on effeminate men, as in the example of Deborah; iii. when there was a shortage of preachers and teachers (as in the New Testament examples). MS Harl. 31, fos $196 \mathrm{r}, 221 \mathrm{r}$.

${ }^{27}$ Ibid., fo. $199 \mathrm{~g}$, where Brut's casuistry on $1 \mathrm{Tim}$. ii (see note ${ }_{4} 4$ above) is dealt with. ('Et nota quod non dicit statuo quasi ex suo statuto primitus emanasse sed dicit non permitto simple sicut nec Christus hoc permisit ...') The case against Brut cited this passage against him, reversing the argument. If women were priests they would be allowed to preach, which (as I Tim. ii showed) is heretical. Ibid., fo. $218 \mathrm{r}$.

${ }^{28}$ Ibid.. fo. 196v: 'omnis sanctus est sacerdos'; 'omnis mulier electa bona est sancta ergo omnis talis est sacerdos'; 'Inagis dignus bonus laicus et mulier bona malo presbitero ergo magis aptus ad opus dignum conticiendi. Conficere autem corpus dominicum est opus dignissimum ergo ad illud est laicus bonus et mulier bona magis apta'. The Lollard arguments on this point-against which a large part of the reply was addressed-are summarised fos $196 \mathrm{v}-197 \mathrm{r}$. For some of Brut's arguments against the ministry of evil priests see Reg. Trefnant, 349 .

29 'magis vult [spiritus sanctus| operari per bonum laicum et pro illo et per mulierem sanctam quain per malum presbiterum'; 'si ergo mulier habeat bonitatem vite et ordinetur cur non potest consecrare'. MS Harl. 31, fos $196 \mathrm{v}-197 \mathrm{r}$. 
principal priestly power, it was also necessary to answer the claim that women could administer other sacraments, especially confession and baptism. Brut, who like a good many other Lollards denied the necessity of oral confession to a priest and the utility of priestly absolution, conjoined these heresies with claims for a lay ministry. He found in Christ's words, 'Receive ye the Holy Ghost ...' (John xx. 22-3) the right of baptised Christians to forgive sins, and among the powers he attributed to women was that of binding and loosing. Central to this argument were the assertions about baptism, since 'everyone who baptises has the keys of the kingdom of heaven, and the layman in baptism thus equals the priest'. Hence the claim that the right of women to perform this sacrament in times of need conferred on them competence to perform other sacraments, the eucharist included ${ }^{30}$ The main argument against this was the inherent difference between baptism and the eucharist: one being essential for salvation, the other not. ${ }^{31}$ In any case, as Brut himself conceded (a point not missed by the other side), ${ }^{32}$ the permission to lay persons was only granted in the absence of a competent cleric, and though God could indeed act through a woman pronouncing the baptismal words, she did not by that process herself confer grace. Women's role in baptism had no bearing whatsoever on the office of the eucharist.

The heretical case took the argument from history beyond the Bible. Besides claiming that presbiterisse et sacerdotisse had existed in the early Church, ${ }^{35}$ Brut rashly advanced in support of women's ability to confer orders the example of the mythical Pope Joan. If, he maintained, the Church denied her ordinations, then subsequent priestly orders must be in doubt; contrariwise, to accept them was tantamount to accepting good women as priests. Brut's opponent, taking aim at this easy target, replied that the alleged two-year reign of the female pope, if it ever existed, argued exactly the opposite of what was claimed. For, as the rest of Joan's story showed, any acts she might appear to have performed with priestly powers were void and quashed by the Church, and if office were to be based on merit, the final scandal of this woman-reportedly chosen for her excellence of learning and character-pointed in the opposite

${ }^{30}$ Reg. Trefnant, 330; ct. Foxe, Acts and Monts., iii. 168. 179. As reported in Reg. Trefnant, $345^{-6}$. Brut's claims for the female ininistrant mentioned all the sacraments except contirmation. Cf. also 324-36 for his discussion of the related questions of the power to bind and loose, confession and baptism, and 362-3, nos. 9. 16 and 19 of the charges against him. The counter-arguments are to be found in MS Harl. 31 . fos $201 \mathrm{vff}$., and $219 \mathrm{r}$ If. and Reg. Trefnant, 370-1, 384-5.

${ }^{31}$ For Wycliffe's arguments on these lines see below p. 460 .

32. MS Harl. 31, fos $201 v$, 202r. Cl. Reg. Trefnant, $345-7$, where this proviso is mentioned four times. One might reflect that it could make little difference to a heretical ministry which would ipso facto exclude those comperent in the church.

${ }^{y s}$ MS Harl. 31 , fo. 197 r. On the development of the female diaconate in the East during the patristic age see Bailey, Man-Woman Relation, 66-9. 
direction. 'I am amazed', concluded the rejoinder, 'that he believes this deed strengthens his case, when it is annulled and reprobated by God and the whole church. ${ }^{34}$

Walter Brut's eccentric learning led his defence of women into some remarkable quirks. On the example of the Virgin and women's capacity to generate and nourish the Hesh he attempted to construct a defence of female powers to make the body and blood of Christ. Assertions about the irrelevance of sex to priestly office were linked with postulates on the possible transmigration of souls between the sexes and the feasibility of physical sexual change. ${ }^{35} \mathrm{He}$ was learnedly controverted at all points, not least on the grounds of logic. To claim that women could consecrate the eucharist was the equivalent, said the opposition, to saying that a woman can contract matrimony simultaneously and singly with her father and son; that a nun consecrated to God can marry a professed religious or even the supreme pontiff; that women can make the sun and moon and stars, raise up a great mountain and cast it into the sea; that any woman can conceive and bring forth God and redeem the world; make the blind to see, the deal to hear, and the dumb to speak. The monstrosity of these propositions was such that anyone preaching them deserved to have his tongue cut out. ${ }^{36}$ Women should not preach, and no ministry could belong to them. Such rights as they had to instruct were strictly limited to private occasions and the hearing of women and children. The teaching of men in public was utterly forbidden them. ${ }^{37}$ Woman, imperfect in

st MS Harl. 31, fo. 204v "miror ergo quod ipse credit pro se valere hoc factum quod a deo et tota ceclesia dei adnullatum est et reprobatum'; ct. fo. $222 \mathrm{~V}$ and B.L. MS Royal 7 B III, fo. $4 \mathrm{f}$ lor the similar conclusion in the other disputation; "miror ergo quomodo lollardi hanc historiam pro se audent allegare per quam oppositum propositi illorum a deo et universali ecclesia declaracur'. Brut's case on this matter (Reg. Trefnant, 346 ) is stummarised in MS Harl. 31, fos 202r, $220 r$, no. 12. Cf. below p. 460 for Wycliffe on Pope Joan. whose imaginary ninth-century reign was finally disposed of by J. J. I. von Disllinger, Die Papst-Fabeln des Mittelalters, Stuttgart 1890, 1-53. In the story the choice of a woman was explained by her great intellectual capacity, but atier two years' reign she gave birth while processing to the Lateran.

${ }^{35}$ MS Harl. 31, fos $198 \mathrm{r}-\mathrm{v}, 219 \mathrm{v}, 222 \mathrm{v}$. This last point was supported by reference to Albert the Great's De Animalibus. Cl. Albertus Magnus de animalibus libri xxvi, ed. Hermann Stadler (Beiträge zur Geschichte der Philosophie des Mittelalters, vols. xv-xvi, Münster 1916-21), 1226, lib. xvilı, tract. 2, cap. 3. The same work (cf. 573, lib. vill, tract. 1, cap. 1) was also cited by Brut's opponent (MS Harl. 31, fo. $21 \mathrm{gr}$ ) on woman's contentiousness and instability. For a view of woman's superiority as having conceived God. see Eileen Power, 'The Position of Women'. in The Legacy of the Middle Ages, ed. C. G. Crump and E. F. Jacob, Oxford $19.51,402$.

${ }^{36} 1$ have here contlated the parallel passages in MS Harl. 31, fos $202 \mathrm{r}-\mathrm{v}$, and $220 \mathrm{v}$, both of which. pursuing their case through distinctions of posse llogicum, politicum, phisicum and iuridicum). listed these extravagances to demonstrate the extremity of the heretical error, alike concluding that 'ralis predicatoris lingua meretur amputari'.

"I I bid.. lo. 196r. alter clucidating the circumstances in which women were allowed to reach (e.g. abbesses those subject to them in the cloister, and housewives other women and childrenl. The inain biblical passages were 1 Cor. xiv. $34-5$ and 1 Tim. ii. 11-12. 
nature, physically impure, ${ }^{38}$ formed for subjection and unfit for authority, was totally debarred from priestly orders. How was it possible that throughout the whole history of the Church up to the present, women had been excluded from the priesthood, unless this was according to divine precept? ? $^{39}$

Thanks to Walter Brut's heady theologising and the seriousness with which it was viewed, we can learn a lot about his heretical defence of women. To that extent his case was exceptional. He was not alone, however, in making claims for women priests. One of the charges laid against William White in September 1428 was that he had taught 'that all pious and just livers, of either sex, have equal jurisdictional power to bind and loose here on earth; so that the power of binding and loosing granted to priests does not exceed the power of other perfect, men or women'. White confessed to this. He utterly denied, however, another more serious accusation that followed. According to this he had believed, aflirmed and taught that "every faithful person in Jesus Christ is a priest of the elect church of God' (quod quilibet fidelis in Christo Jesu est sacerdos electae ecclesiae Dei). Also, it was alleged (with circumstantial detail) he had practised what he preached to the point that on the previous Easter Sunday, in his room in the parish of 'Bergh', he had shown a lay disciple how to celebrate a domestic communion, breaking bread, giving thanks and distributing to those present with the words, 'take and eat in memory of Christ's passion'. ${ }^{40}$

White's denial notwithstanding, a number of his followers admitted, during the months of intensive investigation that followed his condemnation and death, to holding just such views of the priesthood. Margery Baxter, for instance, a close disciple of William W'hite, had

so Woman's menstrual impurity disqualified her from a ministry which required physical purity under the new law as under the old (citing Leviticus xxi on the physical requirements for priests); on this taboo see Joan Morris, Against Nature and God, London 1973, 10.5-12. MS Harl. 31, fos 199v, $21 \mathrm{gr}$.

${ }^{39}$ lbid. fos $199 v-200 r$ 'Non est verisimile quod ecclesia dei a Christo usque modo cotum genus mulierum exclusissimum a sacerdocio et suscepcione ordinum et a tam nobili actu sine precepto Christi ergo cum per ecclesiam omnes mulieres ab huiusmodi excluduntur videtur quod hoc ecclesia faciat ex precepto divino'; cf. fo. 21 gr (= MS Royal 7 B III. (o. 2v) 'Non est verisimile quod a principio mundi tam in veteri lege quam nova totum genus mulierum fuisset exclusum a sacerdocio sine auctoritate dei vel racione naturali. Sed a principio mundi usque modo totum genus mulierum a sacerdocio fuerat exclusum ergo hoc factum est auctoritate dei vel auctoritate racionis naturalis et sive unum sive aliud detur hoc factum est auctoritate dei ergo auctoritate dei mulieres a sacerdocio sunt excluse'. (The transcriber seems to have omitted a word after 'huiusmudi' in the former passage).

${ }^{40} \mathrm{It}$ is implied, therefore, that he omitted the words of institution, 'Hoc est enim corpus meum'. Fasciculi Zizaniorum, ed. W. W. Shirley, R.S., London 1858, 422-4; Tanner, Norwich Heresy Trials, 33 , n. 14 identifies the place as probably Burgh Apton, Norfolk. The wording of Article xii, which White denied, is close to Wycliffe; see below, pp. 460-1. 
evidently learnt from him her view that 'every man and woman who share the opinions of the said Margery are good priests'. Sybil Godsell likewise believed that 'every faithful man and every faithful woman is a good priest and has as good power to make the body of Christ as any ordained priest', and Hawise Moon (whose husband, like Sybil's, gave accommodation to schools of heresy, which Hawise attended) also endorsed this opinion. Nor was it only women who spoke of women's capacities. Sybil's husband, John Godsell, a parchment-maker of Ditchingham in Norfolk, held this view, as did John Skilly, miller of Flixton, a few miles across the county boundary in Suffolk, who confessed that 'I held and affirmed that every true man and woman being in charity is a priest, and that no priest hath more power in ministering of the sacraments than a lay man hath.' Both Skilly and Godsell had received William White in their houses, and both were given the severe punishment of seven years' imprisonment, suggesting serious commitment to the sect. Another of White's lay disciples to confess and abjure this error was John Skylan of 'Bergh'. He was a member of the heretical school in the village where the illicit communion was said to have been celebrated. ${ }^{+1}$

Statements of this kind (which were still being uttered at the end of the fifteenth century $)^{42}$ might be taken not so much as claims for a new universal priesthood, as denials of the claims of the existing priesthood. Anti-sacramentalism was common among the heretics, ${ }^{43}$ and denials of priestly powers were accompanied by attacks on the pope as Antichrist and on the evil lives and vices of those 'called priests' who were 'no priests'. "The idea of every true Christian man and woman as priest was in a sense a negative as well as a positive proposition. Negatively it derived from the heretics' rejection of the traditional ministry and sacraments (of baptism, confirmation, marriage and penance) as obstructions between the individual and God. Positively, and more important, the concept of the lay elect as ordained of God was the direct result of regarding the Church as the congregation of all true believers, Wycliffe's universitas

"Norwich Heresy Trials, 49 (ct. 42 ), 57 (cf. 52), 60-1, 67, $140,142,147$.

${ }^{42}$ One example is the assertion abjured in 1499 by John Whitehorne, rector of Letcombe Basset (Berks.), that Christ at his ascension "left his power with his Apostles and from them the same power remaineth with every good true Christian man and woman living virtuously as the Apostles did, so that priests and bishops have no more authority than another layman that followeth the teaching and good conversation of the Apostles'. Claude Jenkins, 'Cardinal Morton's Register', in Tudor Studies presented . . to A. F. Pollard, ed. R. W. Seton-Watson, London 1924,48 ; Thomson, Later Lollords, 80, 82, 85-6.

${ }^{43}$ Ibid.. 2 $\$ 4-5$; Lambert, Medieval Heresy, 268-9. The Norwich heresy trials of $1428-31$ illustrate the anti-sacramental aspect of Lollardy very clearly.

${ }^{44}$ Norwich Heresy Trials, 141, cf. 147. 
fidelium predestinatorum. ${ }^{+5}$ It was to be defined spiritually, not structurally, individually rather than formally.

Lollard priests were therefore less than 'priestly'. For by their very definition, the sacerdotal role was greatly altered-diminished as well as impugned in orthodox eyes. "No priest in earth has power to make the sacraments . . .'; 'No priest has power to make God's body in the sacrament of the altar, but God made all priests, and no priest has power to make God, for God was made long time ere the priests were made'. ${ }^{46}$ The ministry that mattered above all was the ministry of the Word.

A preaching ministry-male or female-was very different from a celebrating ministry, and the administration of the sacrament of the altar was critical. As the doctors who replied to Brut's heresies and errors pointed out at his trial, his arguments about the priestly powers of women had to be considered together with his denial of the sacrificial nature of the mass. ${ }^{47}$ There was an integral connection between the denial of transubstantiation and the claim for a female priesthood. If one denied, as Brut did, that the mass was other than commemorative, ${ }^{48}$ the administration of the sacrament did not involve the miraculous change of elements. The priestly role was accordingly depreciated.

Looking at it slighty diflerently, one might say that the idea of a priesthood of all believers, in which men and women were equal participants, was a logical concomitant of denying transubstantiation. Taking the miracle out of the eucharist reduced this sacrament to the level of the others and opened it to the ministry of every Christian believer, regardless of sex. This idea was given particular publicity in the twelve conclusions of 1395. The lourth point of this manifesto attacked the idolatry of the 'fained miracle of the sacrament of bread', referring to Wycliffe's words in the Trialogus; 'quod panis materialis est habitudinaliter corpus Christi'. A further deduction followed. 'For we suppose that on

15. Johannis Wyclif Tractatus De Ecclesia, ed. J. Loserth (Wỵclif Soc., London, 1886). 37. cl. 2. Cl. the view of John Burell 'quod ecclesia catholica est anima cuiuslibet boni Christiani' (.Vorwich Heresy Trials, 77), or that of William Wakeham. in Peasants, Knights and Heretics, ed. R. H. Hilton, Cambridge 1976, 287. The genuine historical case behind this redefinition of the Church was doubtless less important for such Lollards than it was for Wyclifle. For a helpful discussion of the concept of priesthood in the early centuries of the Church (when laymen were seen as able to baptise and offer liturgical sacrifice in case of necessity), showing how the character indelebilis developed with sacramental doctrine, see Hans von Campenhausen, Tradition and Life in the Church: Essays and Lectures in Church History, trans. A. V. Litcledale, London 1968, 217-30.

${ }^{16}$. Norwich Heresy Trials, $81,115$.

"Reg. Trefnant, $279,284,33^{6-41}, 3^{6} 4$. While it is clear that Brut's view of the mass denied a change in the substance of the bread, the opponents of his thesis about women devoted a lot of attention to showing that women could not convert the bread and wine into the body and blood of Christ.

${ }^{48}$ For William White's denial of transubstantiation see Fasc. Ziz., ed. Shirley, 418-19, 423. This was of course one of the common heresies of the Lollards. 
this wise may every true man and woman in God's law make the sacrament of the bread without any such miracle. $\$ 9$

Roger Dymoke took up this point in his answer to the manifesto. Were the heretics denying that the usual priesthood was descended from that instituted by Christ? If they were not, what justification could there be for altering the Church's traditional forms? If they were, such a change of essence amounted to destroying the evangelical law, failing to be Christian. This, by implication, was what the heretics were doing in asserting that every good Christian could make the body of Christ in the sacrament and in denying the established priesthood the power to bind and loose. Christ instituted no such priesthood among his apostles, nor did any such exist in Rome, like that of the heretics in their conventicles at Oxford and London, "where women (whom they call virgins, but in fact their whores) have, I cannot say celebrated, but rather profaned masses, of which they are publicly and manifestly convicted, for "as with the people, so with the priests" (ct. Isa., xxiv. 2). ${ }^{50}$

Was there anything more than rhetoric in this accusation? Were the heretics' vindications of women priests ever acted on, or did they remain confined to the sphere of theoretical discussion? There are a few pieces of evidence which may be brought to bear on Dymoke's statement and the possible existence of women celebrants.

First there is an extradordinary episode related by Henry Knighton under the year 1391 -the year when Brut first appeared before the authorities in Hereford. 'In those days', wrote Knighton,

there was a certain matron in the city of London who had an only daughter whom she instructed to celebrate mass, and she set up an altar with its lumishings in her secret chamber, and got her daughter for many days to dress as a priest and go to the altar and to celebrate mass after her manner: but when she reached the sacramental words she prostrated hersell before

${ }^{43}$ Rogeri Dymmok Liber, ed. H. S. Cronin (Wỵclif Soc.. London, 1922), 89-90; for Wycliffe's view of the eucharist in his Trialogus see Gordon Leff, Heresy in the Later Middle Ages, Manchester 1967, ii. 555; Selections from English Wycliffite Writings, ed. Anne Hudson, Caumbridge 1978 (cited hereafter as Hudson, Selections), 25 and notes p. 152 ; cf. 19, 22, 148 lor the much more restrained view advanced on this point in another Lollard text (though one wonders whether this is to be taken at face value or whether it should be seen as a casuistical argument intended to help heretics under threat of examination). It is worth noting that in the third of the twelve conclusions (cf. also no. 11) priestly chastity was attacked on the grounds that the law of continence was invented "in prejudice of women". William White, who married after his abjuration in 1422. was one who acted on this belief. (Fasc. $Z i z ., 420-1,425-6)$. Another was William Ramsbury, on whom see below and Lainbert, Hedieval Heresy, 239.

so Rogeri Dymmok Liber, 63-4 (my italics), cl. 108-9. Dymoke alludes to conclusion 2 on existing orders and conclusion 9 on the power to bind and loose. In view of the reports of London events discussed below it is relevant to note that Dymoke. an Oxford doctor of theology, was by 1396 regent of the Dominican convent of Blacklriars in London. Emden. Biog. Reg. Oxjord, i. 617 . 
the altar and did not consecrate the sacrament; but rising completed all the rest of the mass to the end with her mother assisting and attending her devotion. ${ }^{31}$

This went on for some time until the secret escaped through a woman neighbour who had attended the ceremony. Report came to the bishop of London (Robert Braybrooke). The priestess was discovered, her priestly tonsure ${ }^{52}$ exposed to public view, and she herself was put to penance.

It is conspicuous, particularly in view of the extended treatment which he gives to the development of Wycliffite heresy, that Knighton recounts this story without a mention of Lollardy. He leaves the tale as it stands - an isolated event, from which the reader might draw his own conclusions. We might, however, set this incident (as Knighton almost certainly could not) beside the case of William Ramsbury, a layman who had been proceeded against for heresy by the bishop of Salisbury two years earlier. He too had received an illicit priestly consure; he too had been celebrating unorthodox masses in orthodox vestments; he likewise was not named a Lollard, though in Ramsbury's case there is sufficient additional material to make it clear that he must be accounted such. Also, which is worth particular notice, we know from details of the manner in which he celebrated mass that William Ramsbury did so without the words of institution. ${ }^{53}$ This omission, to which Knighton drew attention in the celebration of the London woman was, as I have indicated, wholly consistent with the Lollards' denial of transubstantiation-a denial which Ramsbury had to abjure.

If the London incident could once (like Thomas Walsingham's reporting of the Salisbury case) have been verified in official records, that option no longer seems open to us. Word of such scandals certainly got round, however. Curiously similar to Knighton's tale is the curt notice given by Walsingham in his mention of the heretic John Claydon, a skinner of London who was burned in the city, after twenty years' heresy, in 1415. Claydon, Walsingham tells us (misnaming him William), had taken his heretical insanity to the extent of making his daughter a priest to celebrate mass in his own house, on the day that his wife, rising from childbirth, should have gone to be churched. The same story is repeated in the later abbreviated version of the chronicle, though in the printed version

3 Knighton, ii. 316-17; for a comment on the incident see B. L. Manning. The People's Faith in the Time of Wyclif. Cambridge 1919, rep. 1975, 138. It seems from what Knighton says, that Braybrooke preached against these doings in St Paul's.

5: It was argued against Brut (MS Harl. 31, fos $199 \mathrm{r}, 218 \mathrm{r}$ ) that if a woman were to be priest she would be capable of the tonsure, which would be against \& Cor. xi. 6 ('. . shame for a woman to be shorn or shaven'). Brut himself, however. indicated rather that tonsure might be a 'sign of Antichrist', and contrary to the practice of the early Church. Reg. Trefnant, $34^{1-4}$.

${ }^{53}$ For Ramsbury see Anne Hudson, 'A Lollard Mass'. J.T.S. x.s. xxiii (1972), 407-19. Walsingham. Historia Anglicana, ed. H. T. Riley (R.S., London 1863-4), ii. 188, reports the incident - as Knighton does his-without names. 
that we have (mistakenly taken from a poor recension) the unambiguous fliam of the best manuscripts is changed to filium. ${ }^{5+}$ There is no mention of any such offence in the full record that survives for Claydon's last trial in 1415. If, however, we allow for the possibility that the chronicler was referring back to some earlier incident in Claydon's heretical career which might have been dealt with in earlier proceedings, this lack would not be inexplicable. ${ }^{55}$ In any event these two independent stories from the chroniclers of Leicester and St Albans deserve joint consideration. Is it significant that in both cases it was reportedly the daughter who celebrated? Whatever the Lollards said against vows of chastity, one might perhaps link this with Dymoke's remark about virgins profaning masses.

If the 1390 s brought these goings-on into the limelight, their notoriety was not forgotten thereafter. Three other contemporaries, two of whom were writing in the 1420 s, adverted to Lollard views on women priests. One such charge (not precisely datable) comes from the pen of Friar Daw, who accused the heretics-among their other sins-of upholding the right of women to act as priests.

And yet your sect susteynes wommen to seie massis,

Shewyng to trete a sacrament as preestes that thei were.

Reversynge holy doctours \&c decree of Holy Chirche. ${ }^{36}$

In reply Jack Upland rebutted this charge, accusing Daw of his habitual wiles and of ignorance of those he despised. 'But as wele of her [their] sacryng as wymmen syngynge messe/al wey thou usest the craft of thyn old fader'; it was incumbent on Friar Daw to prove his charges. ${ }^{57}$ Yet may there not have been an element of evasion in the rejoinder? Atter all,

s4 The St Albans Chronicle 1406-1420, ed. V. H. Galbraith, Oxford 1937,89; Walsingham. Historia Anglicana, ii. 307. Riley, though well aware of its derivative nature chose 'inexplicably'-as Galbraith remarks-to base his text on Arundel MS vii in the College of Arms (compiled c. 1422-30). Two earlier and better texts which both have a clear 'ut eciam filiam propriam sacerdotem constitueret' where Riley prints 'filium proprium', are Corpus Christi College MS 7, fo. 84 r, and MS ${ }_{195}$, fo. $447 \%$. (See Galbraith's edition, pp. $x-x i, n$, xxvi, lix. for these two manuscripts, the former of which contains probably the earliest version of this section of the short chronicle, the latter being apparently copied from it.)

${ }^{33}$ For the proceedings against Claydon see Thomson, Later Lollards, 140-2. Claydon was imprisoned in Conway Castle in 1395, and the fact that his journey there was paid for by Robert Braybrooke, bishop of London 1381-1404, suggests the possibility that action was taken against him at this time by the latter. No record of this, nor of any other heretical proceedings at this timc, survives in Braybrooke's register. though we know from other sources that he took action about now against William Thorpe; John Lydford's Book, ed. Dorothy Owen, London 1974, 11, 108-12. If Braybrooke's proceedings of this kind were recorded (as were, for instance, Bishop Alnwick's of $1+28-31$ : in a separate register. now lost, one can surmise that this might have covered the incident described by Knighton.

${ }^{56}$ Jack Upland, 99; cf. notes on pp. 160-1. On the dating of this text cf. gff. esp. 17 , and cf. Hudson, Selections, 182.

"Jack Upland, 172. 
singing masses was not at all the same as saying them, especially for Lollards who objected to mass and other offices being 'sung with high crying'. ${ }^{58}$ And it was the 'sacring', the consecration, which contained the critical words most likely of all to have been omitted in any heretical celebration.

The manifold ills which the preacher John Swetstock (if it was he) attributed to the Lollards in the reign of Henry $v$ included their outrageous question: 'Why should not women be priested and enabled to celebrate and preach like men?' To this one reply was the stock answer that the Virgin, stainless as she had been, and sole repository of the faith as she was at the time of the crucifixion, had not been a priest. Women must not aspire to such heights. 'Take thee to thy distaff', advised the preacher, 'covet not to be a priest or preacher.' 59

Lastly, there is the notice that was given to this matter by Thomas Netter in his Doctrinale. He alludes in a number of places to the Lollards' advancement of women, including statements by Wycliffe and the claims of John Purvey in a work called De compendiis scripturarum, that the office of preaching should extend to women as well as men. ${ }^{60}$ Netter was in no doubt that Lollard women had responded to this call, not only through scriptural readings and preachings at heretical meetings, but also as women priests. The heresy gathered such strength that in the city of London the most foolish of women, set up on stools, publicly read and taught the scriptures in a congregation of men'. ${ }^{61}$ In the populous capital there had also been young women celebrants. ${ }^{62}$ Netter implies that these heretical priestesses existed in the plural, but his most specific references are singular. There was, he related, 'a certain girl, the daughter of a tanner in the city of London, who publicly celebrated masses in English

\footnotetext{
${ }^{58}$ For Lollard objections to church chanting and singing. including at the mass and other oftices see English Works of Wyclif, ed. F. D. Matthew (E.E.T.S.. 74, 1880), 169, 191-2 (quotation at 191); Select English Works of John Wyclif, ed. T. Arnold. Oxford 1869-71, iii. 203, 228,479-82; Hudson, Selections, 23, 86, 149, 181-2; cf. also the arguments of William Thorpe in Fifleenth Century Prose and Verse, ed. A. W. Pollard, Westminster 1903, 140-2: Thomson, Later Lollards, 250.

${ }^{59}$ R. M. Haines, "'Wilde wittes and willulnes": John Swetstock's atrack on those "poyswunmongeres", the Lollards', S.C.H., viii (1972). 152; ct. Hudson. Selections, 125, 202. Cf. the case of John Yonge, a Bristol heretic who abjured in 1449 , who clatined the right ol tiee preaching except for women; Thomson, op. cit., 37. For other such remarks about keeping to the distaff see above p. 3 (Hoccleve) and Thomas, "Woman and ... Sects', 60-1, n 70 .

60 Thomas Netter of Walden, Doctrinale Antiquitatum Fidei Catholicae Ecclesiae, Venice 1757-9. refers to this work of Purvey's, i, cols. 619,637 (Bk. ii, caps. 70, 73), which he says included the claim that women could preach at will. This text (apparently now lost) is discussed by Anne Hudson in a forthcoming article on Purvey which I am grateful to her for showing me in typescript. See below pp. 459-60, nn. 69, 71, for Netter on Wycliffe's defence of women.

${ }^{61}$ Netter, Doctrinale, i. col. $6{ }_{3} 8$ (Bk. ii, cap. 73 ). Once again (cf. above $\mathrm{n} 14$ and p. 450) it was the teaching ol men in public which was specially shocking. in view of the words of $\mathrm{St}$ Paul.

62 Ibid.. i. col. 296 (Bk. ii. cap. 12), iii. col. 199 (De sacramentalibus. cap. 28); cl. iii. col. 371 (De sacramentalibus, cap. 58 ).
} 
before them' ${ }^{63}$ This incident had taken place long before, in the reign of Richard II, but report of it was still current. Whether or not, as seems very probable, Netter was thinking of the tale of John Claydon's daughter, it is worth noticing that he says the heretical masses were in English, and that London is the only location he gives for such priestesses. ${ }^{64}$

We are left, as so often, with more verbiage than substance. It seems most unlikely that there were ever many Lollards-either men or women-who resorted to administering the eucharist. We should certainly expect to learn more about it (in the way of formulated questions, if not answers) if they had, and the frequency with which they denied transubstantiation, coupled with their own belief in the sacramental value of the Word, makes it likely that such ceremony as they had centred upon preaching. 'For the Word is God and God is the Word', as John Whitehorne put it in 1499. 'And therefore whosoever receive devoutly God's Word he receiveth the very body of Christ.' ${ }^{65}$ Silence in this matter is surely indicative. The fact that we hear so little, even polemically, suggests the extreme rarity of such proceedings as illicit ordinations or bowdlerised masses, conducted by male or female celebrants. Skilled the Lollards were in the arts of concealment, but the authorities would have been at their most vigilant to hunt out and suppress any operations so suggestive of a nascent counter-church. ${ }^{66}$

Yet the wisps of reporting that survive (repetitive though some of this may be) cannot be dismissed out of hand. At the very least they are indicative of a certain consistency of attitude among both the heretics and their opponents, and of the parallels between Lollards and earlier medieval heretics. Comparable developments had taken place annong the Cathars and Waldensians. Cathar women were capable of receiving the consolamentum and of joining the ranks of the perfecti, a status which gave them precedence over other believers in the sect, even though they could not hold office in it. Women were also prominent in the Waldensian

${ }^{6 y}$ Ibid., ii. col. 71 (De sacramentis, cap. 7) 'ut tunc tempore regis Richardi II fama personuit. \& usque nunc durat'; cf. col. 185 (cap. 28) '. . . sectatores ejus [Wycliffe], ut publica fama canit, in hac civitate Londoniarum olim instituerunt juvenculam quamdam pro festis diebus, \& dominicis consecrare eis suam eucharistiam'.

${ }^{64}$ The period, location and trade (a tanner might well have been confused with a skinner) seem to point to Claydon, but Walsingham does not say the celebrations were in the vernacular.

is Jenkins, 'Cardinal Morton's Register', 48.

${ }^{66}$ On the little we hear of Lollard ritual see Lambert, Medieval Heresy, 270; Thomson, Later Lollards, $115,161,246-7$. If the catch-phrase 'May we all drink of a cup' found among early sixteenth-century Coventry Lollards was a password one can point to the parallel with Cathars; Moore, Birth of Popular Heresy, 153. The questions about the eucharist framed c. 1428 for examining suspect Lollards, though pointing towards possible rejection of transubstantiation and orthodox consecration of the sacrament, did not envisage lay celebrants-which contrasts with the expectation of lay preaching and. correction of clerical possessioners. Anne Hudson. 'The Examination of Lollards', Bull. Inst. Hist. Research, xlvi (1973), 153.155 and comments $150-2$. 
movement, in which the ability to preach brought them equal leadership with men. The early fourteenth-century inquisitor Bernard Gui regarded Waldensian proclivities towards Donatism as responsible for heretical claims for women priests. 'They say', he wrote, 'that the consecration of the body and blood of Christ may be made by any just person, although he be a layman and not a priest ordained by a Catholic bishop, provided he is a member of their sect. They even believe the same thing concerning women, if they are of their sect, and so they say that every holy person is a priest. ${ }^{67}$

Donatist (or near-Donatist) denials of the validity of the sacraments administered by unworthy priests led to claims for a lay ministry, and these in turn opened the way to further claims and counter-charges. There was a logic, if not a direct link, connecting the error of which Wycliffe was condemned in 1382 , that a bishop or priest, if in mortal sin, does not ordain, consecrate or baptise, ${ }^{68}$ and the supposition of the 1395 manifesto that every true man and woman in God's law could make the sacrament of the bread. Netter was surely right to look back to Wycliffe for the beginning of this story. His speculations-as usual hedged with provisos and in this case largely parenthetical-had set the ball rolling.

Wycliffe touched on the topic of lay celebrants, including women, in more than one work. It seems to me, objected the unfaithful and captious Pseustis in the Trialogus, that you deviate from the opinion of the Church and from scripture, in saying that a layman can consecrate (conficere) as a priest. To which the 'subtle and mature theologian', Phronesis, answers that it seems probable to many that a layman can consecrate. There was the example of St Cecilia who had turned her house into a church. More important, there was the evidence of scripture. I do not think you can show, wrote Wycliffe, that where we read of believers 'breaking bread from house to house' (Acts ii. 46 ), 'that those breads were not the body of Christ, or that only the apostles or priests (presbyteri) did this'. But, admitting this was uncertain, it was undoubted from 1 Corinthians (xi. 24ff.) that this office appertained to 'holy priests' (sacerdotes sanctos), on whom Christ had specially enjoined it. ${ }^{69}$

${ }^{67}$ Religious Dissent in the Middle Ages, ed. Jeffry Russell. New York 1971, 45, cf. 63: Lambert, $76-7$ and, on the effects of Donatist learnings among the Waldensians, 79-80, 163.

${ }^{68}$ Historia Anglicana, ii. $5^{8}$; H. B. Workman, John Wyclif, Oxford 1926, ii. 416 . For an attempt to escape Donatist heresy while arguing that Christians should not receive the sacraments or attend divine services administered by open simonists, lechers, or other 'such vicious men' (putting the stress on the public nature of the sin), see Remonstrance against Romish Corruptions in the Church, ed. J. Forshall, London 1851, 120-34 (art. $\mathrm{xxxv}$ - N.B. the mention of Donatists, 123.

${ }^{69}$ Joannis Wiclif Trialogus, ed. G. Lechler, Oxford 1869, $280-1$; cf. $3^{8}$ for the author's characterisation of the speakers in the text. For Netter's linking of this passage in the Trialogus with the 'profane priestess of the Lollard order' see Doctrinale, ii. col. 185 (De sacramento eucharistiae, cap. 28). 
A few years before this Wycliffe had made some passing remarks about female ministrants in De potestate pape. These asides appeared as part of his argument that priestly orders were all of equal authority, so that a simple priest (simplex sacerdos) was on a par with bishop or pope in his ministry of the sacraments. The papal office resided in virtue, not rank, and anyone-in theory even a layman-could be pope. Christ had given the simple priest all necessary powers, and in case of need a layman was able to baptise. ${ }^{70}$ It was in parenthesis, in considering and answering foreseeable objections to this thesis, that Wycliffe raised the topic of women priests. It is important to bear in mind the strictly academic nature of the context. Wycliffe was not discussing women priests as such; he was using this hypothetical contingency to counter possible objections to his view of the priesthood.

Firstly, he answered the argument that if a layman could baptise he was capable of administering the other sacraments, so that God could impart "not only to a layman but to a woman or other irrational person the power of consecrating and adininistering any sacraments'." Wycliffe denied this. His main reason was that later used against Brut. Baptism, because of its special scriptural authority and indispensability for salvation was unlike the other sacraments, so that arguments about lay ministrants deduced from lay baptisin were of no validity. Could a woman be pope? What Wycliffe had to say about the story of Pope Joan in considering this question again seems closer to the view later expressed by Brut's opponent than to that heretic's own thinking. It could indeed be argued, said Wycliffe, that sin, not sex, was what chiefly disabled Joan, since monstrous sin in a ministrant or communicant was more serious an obstacle than physical deformity 'or the distinction of sex in a predestined woman of outstanding virtues'. But against this had to be set the fact that even the "holy woman is not allowed, because of the weakness of her sex, to preach the gospel publicly in church', and that limitation excluded her, as much as any angel, from the headship of the Church. ${ }^{12}$

Wycliffe also dealt with the objection that his view of the priesthood was tantamount to abolishing priests and ordination. Not so, he maintained. If we look to Christ and the apostles, and to words of Augustine and Chrysostom, it is evident that all faithful Christians, the

70 Johannis Wyclif Tractatus de Potestate Pape, ed. J. Loserth. London 1907, 307, 272. Leff, Heresy in the Later Middle Ages, ii. 531-3.

"De Potestate Pape, 308. Cf. Netter, Doctrinale, iii. col. 372 (De sacramentalibus, cap. 58) where Wycliffe's 'femine ac alii irracionali' has become 'femine sive bruto'. According to Netter (col. 371 ) 'ipse Wicleffus non erubuit libro suo de Papa pluries laborare pro femina, ut sit apta sacerdos ecclesie, episcopus, sive papa'. Cf. also cols. 376-7ff. Though Netter remarked on the ambiguity of Wycliffe's tortuous expressions, he does not seem to have made sufficient allowance for this in the deductions he drew from Chapter xi of De Potestate Pape.

${ }^{12}$ De Potestate Pape, 308, 271-2-referring to 1 Cor. xi. The example of angels was also used in the refutation of Brut's view of sacerdotal office (MS Harl. 31. fo. $216 \mathrm{r}-\mathrm{v}$ ). 
holy people, were priests of God, and in that spiritual sense 'all holy men and women members of Christ are priests'; 'woman is priest'. The sacraments would not vanish if there were no pope; it is sin, not office, that differentiates between ministrants. 'Every Christian and specially a good priest is sacerdotal', but no one should presume to think himself directly ordained of God and the Church should rest content with the two orders of deacon and priest. ${ }^{73}$

Despite the tangential and perhaps confusing character of these remarks, they were set in a challenging context, and magisterial ambiguity was no bar to controversy. Where Wycliffe hinted others asserted and acted. His reformulation of the Church as the body of the elect brought him virtually to deny the existing order of priesthood and seemingly to elevate the virtuous layman over the constituted ministers of the Church. 'Every predestined layman is a priest. ${ }^{\prime 4}$ As was perceived at the time, the logical outcome of this view was a ministry of both the sexes. Some Lollards' fidelity to this most dangerous aspect of Wycliffe's thought carried them well beyond the heresiarch, yet still with a discernible continuity of intention. Those on the receiving end of heresy, whether or not they were sufficiently knowledgeable about continental heresies to anticipate such developments, ${ }^{75}$ could scarcely have been taken by surprise.

Lollard women priests? The conclusion is indefinite. The Lollards, who produced some famous women preachers in their time and promoted the religious and educational equality of the sexes, had at least raised the theoretical possibility of having women priests. The theory was itself startling, shocking enough to prompt rumours as well as counter-arguments. Rumour there certainly was at that critical moment in the development of the sect in the 1390s, when academics and popular evangelisers were beginning to take diverging ways. If the exceptional extremist (or extreme feminist) did resort to surreptitious female rites, the most likely time was then, the most likely place London. Having not a single name to go on, we must leave the record as it stands-as plausible gossip. Yet the talk itself is remarkable enough, and gossip is also part of history.

\footnotetext{
13 De Potestate Pape, 312-13, 315 ('Sicut enim omnis christianus et specialiter bonus presbiter est sacerclos ... .).

"From De Eucharistia, quoted Lelf, Heresy in the Later Middle Ages, ii. 520, n 2 ; cf. 519-20. $5^{25-6}$ for references to this and other such views described (p. 520, cf. p. 525) as 'the single most destructive and heretical feature of Wyclif's teaching".

${ }^{15}$ For a suggestion of parallels between heresies of Waldensians and Lollards made by Thomas Palmer see Reg. Trefnant, 400.
} 